Teaching \& Learning (2011) 6(1), 74-82

\title{
Building teachers' capacities one teacher at a time within a learning community framework: A retrospective analysis
}

\author{
DR. SONYA PANCUCCI \\ Brock University \\ KATHRYN CORNETT \\ Literacy Improvement Project Teacher
}

\begin{abstract}
The purpose of this paper is to present how teachers build capacity within a learning community. Two participant researchers, acting as facilitators and coteachers in an Ontario elementary public school literacy initiative, applied a learning community model for professional development to determine its impact on teachers' capacity, and on students' standardized test scores. Data collection included meeting notes from weekly modelling sessions and bi-weekly learning community meetings, field logs, reflection statements from teachers and principal, and documents (such as team-constructed lesson plans and lesson materials).

Findings indicated that the use of a learning community to promote collaborative planning, sharing of effective or best practices for teaching, and modelling of literacy components, was valued by teachers. As well, the collaborative learning experience encouraged teachers to take on increasing responsibilities for planning and delivering lessons, promoting a cohesive learning situation for students, as indicated by significantly improved standardized test scores as measured by the Education Quality and Accountability Office Test (EQAO Test), and staff attitudes towards the use of the learning community, as a means of professional development.
\end{abstract}

\section{Introduction}

According to Schmoker (2006), schools set improvement goals, after which teacher teams prepare lessons and adjust teaching based on formative assessments - a viable learning community. Schmoker (2006) argues:

If we wish to resist the creeping dissolution of conventional public schools, we have to wake up to the fact that the experts are among us. The current system prevents these experts - practitioners - from acting on the best practices they already know and should be refining together continuously ... [Additionally] professional learning communities 
will allow us to make dramatic progress almost exclusively on the basis of in-house expertise. (p. 6)

The learning community model is purported to produce effective professional development that improves teaching and learning (DuFour, 2004; DuFour \& Eaker, 1998; Fullan, 1995; Louis, Kruse, \& Marks, 1996; Scribner, Cockrell, Cockrell, \& Valentine, 1999; Skytt, 2003). This paper describes the experience of two participant researchers, the Literacy Improvement Project Teacher (LIPT) and Learning Resource Teacher (LRT), who facilitated and co-taught with Grade 3 teachers within the framework of a learning community. The purpose of the study was to determine some key characteristics essential to a learning community, designed to build teacher capacity, effectively bridging the learning community theory to practice, gap at the school level.

\section{Philosophical Perspective}

This study is based on a social constructivist view of human development (Mitchell \& Sackney, 2000) that views the learning community as a vehicle for capacity building (Lambert, 1998) that values members’ prior experiences. Research has indicated that the complex learning community model provides effective professional development for teachers (DuFour \& Eaker, 1998; Eaker, DuFour, \& DuFour, 2002; Lambert, 2003, Mitchell \& Sackney, 2000), in which the community builds on teachers' prior experiences, and provides opportunities for members to reconstruct new professional narratives, as they share effective practices and interact with one another. Tafel and Bertani (1992) redefine professional development as teachers’ means of creating their "own carefully articulated goals to improve their schools, their relationships with each other and the teaching processes for students” (p. 12). In a learning community, profound improvement happens from within, through a search for meaning, relevance, and connection, which is an expression of members' capacities in search of teaching and learning improvement (DuFour \& Eaker, 1998).

Leadership from administrators that influences this type of community building is often key to the success of the initiative, and Blase and Blase (2004) suggest that principals' leadership is based on the following beliefs:

We are all learners; thus, school is a "community of learners,” including [all stakeholders]. 
We are all lifelong learners; thus, our goal is to prepare students for lifelong learning by teaching them (helping them learn) how to learn.

We are all coaches; thus, we learn from each other and help others learn.

We are all colleagues and collaborators.

We openly discuss our views and work toward consensus. This includes dialogue about curriculum, instruction, and program administration vis-à-vis students, teachers, administrators, supervisors, and parents. (p.65)

Our paper is positioned within a variation of Mitchell and Sackney’s (2000) theoretical framework for building a community of learners through mutually influencing and interdependent functioning of teachers’ capacities. Mitchell and Sackney (2000) identify three levels of capacity: personal; interpersonal; and organizational capacities. In our work, we focused on the three capacities of individual teachers, where each capacity is located and developed within each member of the learning community. The Pancucci (2008) framework varies from Mitchell and Sackney’s (2000) original intent, because it views capacity-building as a domain for individual teacher professional development, rather than for building collective capabilities or organizational systems, and will be used to frame the data analysis for this research, where the goal was to identify key factors that describe how teacher capacity influences learning community implementation.

\section{Background}

Standardized tests like the EQAO Test have become key indicators of effective schools. Data from this test has been used to shape school improvement planning (SIP), and allows teachers and administrators to focus, with precision, on the curriculum teaching-learning cycle. Last year, the principal, the Literacy Improvement Project Teacher (LIPT), the Learning Resource Teacher (LRT), and the Directions Team, worked on selecting a focus and “demystifying” the Grade 3 EQAO Test. A focus of sharing effective practices targeting identified student needs, where teachers provided professional development to each other within a learning community framework, was used. To achieve this end, the principal established a Grade 3 Rotation, a SIP initiative that included teachers in Grade 3 working together, along with the support personnel (LIPT and LRT), to plan, co-teach, and moderate (mark collaboratively) weekly literacy lessons based on Ontario Ministry of Education curriculum expectations, (e.g., 
making connections from text to real-life, text forms, writing genres, and responding to Open Response questions). For several of the first months of the project, the weekly initiative employed an EQAO Moment to provide strategies for reading and processing questions, employing graphic organizers for generating ideas, and writing templates to respond to higherorder thinking questions. However, our principal believed that the EQAO Moment lasted longer than its name implied, and she renamed the initiative, the Grade 3 Rotation.

\section{Method}

Participants in the learning community included the teachers in Grade 3, and the two participant researchers (the LIPT and LRT support personnel). Although not directly involved in the learning community meetings, perspectives of the principal regarding the influence of the learning community on teacher professional development, were also collected. The members of the learning community met bi-weekly (from January to May 2008) during job-embedded learning community meetings, and each teacher co-taught with support personnel once a week during literacy lessons. During learning community meetings, the members worked together to co-plan, co-teach, and moderate (mark collaboratively) weekly literacy lessons, thereby ensuring consistent literacy instruction in all Grade 3 classes. Teachers observed, supported, and reflected on student learning, while noting new strategies for adoption. Members also dialogued about successes, insights into student learning, and common terminology and expectations for students.

Data sources included recorded minutes from the learning community meetings, participant and participant researchers’ recorded reflections, observation field logs, and documents (such as lesson plans and co-constructed lesson materials). Qualitative data was generated from each meeting or interaction between participant researchers and participants, which was analyzed as it emerged from the discourse through a process of unitizing data into individual thoughts or actions (Erlandson, Harris, Skipper \& Allen, 1993). Categories of unitized data emerged, which were then clustered into themes. The emerging themes were constantly compared and adjusted to accommodate new data emerging from new interactions and discourse (Creswell, 2008). Triangulation for credibility and trustworthiness was ensured through the collection and analysis of multiple data sources and prolonged engagement with participants (Lincoln \& Guba, 1985). 


\section{Findings}

In our investigation, we identified three key factors describing how teacher capacity influences learning community implementation: (a) co-teachers investing time in their Grade 3 teachers, (b) shared effective practices impact on student performance, and (c) principal-driven instructional leadership shaping frameworks like the Grade 3 Rotation for teacher capacitybuilding within the learning community model.

\section{Investment of Time for Building Capacity with Fellow Team Teachers}

The time spent by participants in learning community meetings and observational activities supported capacity-building through 1) opportunities to observe effective practices modelled by support personnel, as well as the other teachers in the community, 2) opportunities for members to share successes, concerns, ideas, and strategies, and effective practices, and 3) opportunities to apply these ideas in their own classroom practice with support, if needed. At first, support personnel (LIPT and LRT) led planning sessions and modelled effective instructional strategies for reading and writing, respectively, in Grade 3 classes. Later, Grade 3 teachers increasingly took on responsibility for, and collaboratively chose, tasks, identified areas for re-teaching, planned and delivered lessons, while support personnel engaged in student encouragement and feedback. Consequently, other outcomes for the Grade 3 Rotation were that teachers built capacity by collaborating and sharing strategies, materials, and plans. Key stakeholders in the learning community (the Grade 3 teachers, the pupils, and the co-teachers (LIPT and LRT) all had a voice in the SIP-process. The principal attributed improved staff attitudes towards this collaborative process of teachers providing professional development for one another through co-teaching and facilitation, within a learning community framework.

\section{Shared Effective Practices Impact on Student Performance}

The learning community model was an effective means of professional development because job-embedded teacher development occurred during the Grade 3 Rotation and Learning Community periods, where lesson planning, review, and collaborative marking resulted in improved EQAO Test scores. Reading Scores improved 24\% and Writing Scores improved 35\% from 2007 to 2008. The principal also attributed improved Grade 3 EQAO Test results to

consistent literacy lessons and enhanced student responses and practices, which were emphasized 
first in the modelling of the support personnel (LIPT and LRT), and adopted by all teachers in the learning community. Consequently, a sharing of ideas, lessons, and intervention strategies for reluctant readers or writers took place, which helped Grade 3 teachers address individual student learning needs.

\section{Principal-driven Instructional Leadership}

Principal-driven instructional leadership shaped the framework of the learning community model employed by the Grade 3 Rotation. Our principal modelled instructional leadership, by providing opportunities for job-embedded learning community meetings, established a procedure for the support personnel (LIPT and LRT) to engage teachers in the planning, co-teaching, and collaborative marking activities, and provided time for observation of one another's' teaching practices. These leadership practices encouraged teacher capacitybuilding within the learning community model.

\section{Teacher Interactions and Learning Events}

Initially, some teachers were reluctant Grade 3 Rotation participants. However, after experience with the co-teaching model, staff found it to be a collaborative effort that enhanced teaching and student learning. In addition, participant adoption of the learning community model was evident in the active teacher participation in learning opportunities. Teacher concerns about “teaching to the EQAO Test," were alleviated after teachers observed that literacy lessons were curriculum-focused. Once engaged in the teaching-learning cycle, the Grade 3 teachers continued similar lessons to reinforce skills taught. Other teachers not involved in the Grade 3 Rotation learning community took notice, and expressed interest in participating in a learning community and wanting to use shared effective practices in their classrooms. The Grade 3 Rotation inspired all staff to be one cohesive team, learning together collaboratively, sharing ideas, materials, and skills.

\section{Conclusion}

Currently, the learning community is the professional development model of choice for many school boards (DuFour, 2004; DuFour \& Eaker, 1998; Skytt, 2003). Research supports its effectiveness for enhancing teaching and learning (Hord, 2001). Schmoker (2006) extends this 
argument to suggest that working in professional learning communities, where the principal, as instructional leader promotes a structure where in-house experts can support and work with team members, which leads to enhanced teaching and student learning. Schmoker (2006) firmly advocates for the process of building teacher capacity by tapping into the strengths and talents of experts already within schools, to support this form of professional development. He states, "Schools that function as professional learning communities are still in a distinct minority. If we truly desire better schools on a large scale, then we have to make these collaborative structures the norm - an expectation from the state, district, and school” (p. 7).

In the Ontario context, the implementation of in-house facilitators would need to be a direction from the Ministry of Education, The Ontario College of Teachers, school districts, and local school levels to ensure continual learning together and sharing of practices. This type of professional development, created at a grass roots level within the context of a learning community, would follow the direction of the Foundations of Professional Practice set out by the governing body, The Ontario College of Teachers. This document states that professional development should support the development of "five interdependent domains of the Standards of Practice for the Teaching Profession - Commitment to Students and Student Learning, Professional Knowledge, Professional Practice, Leadership in Learning Communities and Ongoing Professional Learning” (p. 5).

Within the current reform environment, many school boards base school improvement plans on effective schools research, which supports teacher professional development as important for educational change (DuFour \& Eaker, 1998; Goldberg, 2006), and on the use of learning communities for teacher professional development (Skytt, 2003). Skytt (2003) further supports the learning community as the preferred model for teacher professional development, because it is purported to build processes that improve teaching and learning within schools. DuFour (2007) similarly argues that the learning community "provides a powerful, proven conceptual framework for transforming schools at all levels” (p. 8). However, achieving this change and building teachers' capacity through the use of the learning community model for professional development, is unclear. Hence, our work serves to bridge the theory-practice gap by describing a practical implementation of an outline of a learning community model that effectively allowed teachers to work and learn together, within their own teaching context. 


\section{References}

Blase, J. \& Blase, J. (2004). Handbook of instructional leadership: How successful principals promote teaching and learning ( $2^{\text {nd }}$ Ed.). Thousand Oaks, California: Corwin Press.

Creswell, J. W. (2008). Educational research: Planning, conducting, and evaluating quantitative and qualitative research. Upper Saddle River, NJ: Pearson/Merrill Prentice Hall.

DuFour, R. (2004). What is a “Professional learning community?” Educational Leadership, 61(8), 6-11.

DuFour, R. \& Eaker, R. (1998). Professional learning communities at work: Best practices for enhancing student achievement. Bloomington, IN: National Educational Service.

DuFour, R. (2007). Professional learning communities: A bandwagon, an idea worth considering, or our best hope for high levels of learning? Middle School Journal, 39(1), 4-8. Retrieved from http://www.nmsa.org/Publications/MiddleSchoolJournal/Articles/September2007/Article 1/tabid/1496/Default.aspx

Eaker, R., DuFour, R. \& DuFour, R. (2002). Getting started: Reculturing schools to become professional learning communities. Bloomington, IN: National Educational Service.

Erlandson, D. A., Harris, E. L., Skipper, B. L., \& Allen, S. D. (1993). Doing Naturalistic Inquiry. Newbury Park, CA: SAGE Publications, Inc.

Fullan, M. (1995). Broadening the concept of teacher leadership. Paper presented for the National Staff Development Council in November 1995.

Goldberg, M.F. (2006). Insider's guide to school leadership: Getting things done without losing your mind. San Francisco, CA: Jossey-Bass.

Hord, S. L. (2001). Issues ... about change: Professional learning communities: What are they and why are they important? Southwest Educational Development Laboratory, 6(1), 1-8.

Lambert, L. (2003). Leadership capacity for lasting school improvement. Alexandria, VA: ASCD.

Lambert, L. (1998). Building leadership capacity in schools. Alexandria, VA: ASCD.

Lincoln, Y. S., \& Guba, E. G. (1985). Naturalistic Inquiry. Newbury Park, CA: SAGE Publications, Inc.

Louis, K. S., Kruse, S. D., \& Marks, H. M. (1996). Schoolwide professional community. In F.M. Newmann \& Associates (Eds.), Authentic achievement: Restructuring schools for intellectual quality (pp. 179-203). San Francisco, CA: Jossey-Bass.

Mitchell, C. \& Sackney, L. (2000). Profound improvement: Building capacity for a learning community. Lisse, The Netherlands: Swets \& Zeitlinger.

Ontario College of Teachers. (2010). Ontario College of Teachers: Foundations of professional practice. Toronto: The Ontario College of Teachers.

Schmoker, M. (2006). Results now: How we can achieve unprecedented improvements in teaching and learning. Alexandria, VA: ASCD.

Scribner, J. P., Cockrell, K. S., Cockrell, D. H., \& Valentine, J. W. (1999). Creating professional communities in schools through organizational learning: An evaluation of a school improvement process. Educational Administrative Quarterly, 35(1), 130-160. 
Building teachers' capacities

Skytt, J. (2003). Professional learning communities: Empowering teachers in school improvement. ATA Magazine, 83(4), 5-9.

Tafel, L., \& Bertani, A., (1992). Reconceptualizing staff development for systemic change. Journal of Staff Development, 13(4), 42-45. 